\title{
Contamination of obsterics and gynecology hospital air by bacterial and fungal aerosols associated with nosocomial infections
}

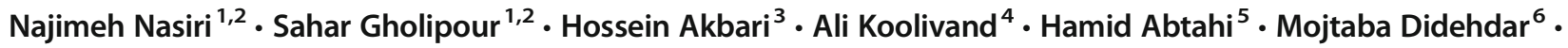 \\ Arezou Rezaei $^{7} \cdot$ Nezam Mirzaei $^{1}$
}

Received: 5 January 2021 / Accepted: 15 February 2021 / Published online: 27 February 2021

(C) Springer Nature Switzerland AG 2021

\begin{abstract}
Bacterial and fungal bioaerosols are a global concern due to nosocomial infections, especially in developing countries. Our study aimed to detect fungal and bacterial bioaerosols in different wards of an obstetrics and gynecology hospital air samples. 240 bioaerosol samples were collected by performing impaction method from different wards of a hospital in the central part of Iran, during two seasons. Fungi genera and bacteria species are recognized by cultivation. Concentrations of bacteria and fungi were ranged from 44 to $75 \mathrm{CFU} / \mathrm{m}^{3}$ and 8 to $22 \mathrm{CFU} / \mathrm{m}^{3}$, respectively. Labor Delivery and Recovery (LDR) and Emergency room had first and second most contaminated air among all the hospital wards. No significant difference between microbial load of wards which used natural ventilation and heating, ventilating, and air conditioning (HVAC) system was observed. The microbial load was not affected significantly by temperature, working shift, and Inpatient Bed Occupancy Rate (IBOR). Fungal load related significantly with relative humidity. Staphylococcus aureus (detected in $48.3 \%$ of samples) and Penicillium (27\%) were the most predominant isolated bacteria and fungi, respectively. The results revealed that the level of bacteria and fungi responsible for nosocomial infections in the air of this hospital is very low. Although levels of microbial contamination are relatively low, it is important to investigate the effect of bioaerosols on nosocomial infections, especially in neonates.
\end{abstract}

Keywords Nosocomial infection · Indoor air pollution $\cdot$ Bioaerosol $\cdot$ Hospital $\cdot$ Bacteria $\cdot$ Fungi

Nezam Mirzaei

nezammirzaei@yahoo.com

1 Department of Environmental Health Engineering, Social Determinants of Health (SDH) Research Center, Kashan University of Medical Sciences, Kashan, Iran

2 Student Research Committee, Kashan University of Medical Sciences, Kashan, Iran

3 Department of Biostatistics and Public Health, Social Determinants of Health (SDH) Research Center, Kashan University of Medical Sciences, Kashan, Iran

4 Department of Environmental Health Engineering, Faculty of Health, Arak University of Medical Sciences, Arak, Iran

5 Depatrment of Medical Mycology and Parasitology, Medicin Faculty, Arak University of Medical Sciences, Arak, Iran

6 Department of Microbiology, Faculty of Medicine and Molecular and Medicine Research Center, Arak University of Medical Sciences, Arak, Iran

7 Environmental Science and Technology Research Center, Department of Environmental Health Engineering, School of Public Health, Shahid Sadoughi University of Medical Sciences, Yazd, Iran

\section{Introduction}

Nosocomial or healthcare-associated infections are introduced as viral, bacterial, and fungal infections which may harm people during their inhabitation in healthcare settings [1]. The World Health Organization (WHO) reported that around $15 \%$ of hospitalized individuals get infected by microbial agents in hospital wards [2]. Although person-to-person transmission is the major route for most infections, evidence show infections caused by some microorganisms like staphylococcus and acinetobacter may transmit through the air $[3,4]$. In the recent COVID-19 pandemic, medical waste management, health care settings disinfection and air contamination monitoring of hospitals have received more attention [5-8]. Hospitals' indoor air should be healthy for patients to breathe and the level of indoor contaminant or outdoor originated pollutants in the air should be reduced [9]. Based on the present population in hospitals, ventilation system, building and environmental conditions, different types, and concentrations of microorganisms may be existing in the indoor air of 
hospitals [10]. Bioaerosols in healthcare settings are originated from outdoor air, respiratory droplets of people, air conditioning stuff, and cleaning activities [11]. Long-term hospitalization and inadequate air exchange rate in hospitals increase the exposure time, and may cause nosocomial infection related to bioaerosols $[1,12]$. The most proportion of nosocomial infections causes by bacteria [1]. Also, fungi genera as ubiquitous microorganisms could be found in different types of indoor environments [1, 13, 14]. Fungal spores because of their small sizes are able to easily transmit between different wards and thorough inhalation may cause allergic response, asthma, and infections $[15,16]$.

Most studies were performed in general or multispecialized hospitals with a wide range of patients and different services and activities $[9,14,17,18]$; Hence, the determination of influencing variables is difficult. Individuals hospitalized in obstetrics and gynecology hospital are mainly pregnant women and neonates who are known as sensitive groups, and their exposure to high levels of bioaerosols may pose a serious risk of infection in these groups [1]. Some airborne fungi and bacteria which have no impact on healthy people may cause serious problems to vulnerable groups in hospitals [19]. Nosocomial infection causes $4 \%$ to $56 \%$ of neonates' death around the world, and this rate increases to $75 \%$ in the middle east countries [2]. Also, in some studies, it has been reported that bioaerosol contaminations of women and maternity wards were the highest level among different hospital wards [18, 20]. Monitoring of bioaerosols level in hospital air is essential to prevent the spread of nosocomial infections. As mentioned, most deaths from nosocomial infections are related to neonates, therefore it seems monitoring of bacteria and fungi concentration in the maternity and neonatal wards air may probably be effective in preventing infection, disease, and death of neonates. The study aimed to determine the air microbial quality, including bacterial and fungal bioaerosols in different wards of an obstetrics and gynecology hospital in Iran, and its association with ventilation, shifts and environmental factors.

\section{Materials and methods}

\section{Description of the sampling sites and strategies}

This study was carried out from September 2018 to January 2019 in a maternity hospital, which was located in the center part of Iran. The hospital has eight separate wards including neonates, Neonatal Intensive Care Unit (NICU), maternity, operating theater, surgery, postpartum care, Labor Delivery and Recovery room (LDR), and emergency room. Sampling was performed from three points in all eight wards of the hospital 1 day a month (for 5 months) in two shifts in the morning and afternoon. A total of 240 separate samples (8 wards $\times 5$ months $\times 2$ shifts $\times 3$ sampling point) were taken for fungi and bacteria. The characteristics of sampling sites are presented in Table 1. During the sampling period, patients and staff were present. Sample collection was performed at a height of about $1.2 \mathrm{~m}$ for $2.5 \mathrm{~min}$ using an Andersen onestage viable impactor (SKC, USA) at an airflow rate of 28.3 L/min. Impactors were fitted with $100 \mathrm{~mm}$ diameter Petri dishes containing Sabouraud Dextrose agar (SDA) supplemented with chloramphenicol and blood agar (BA) for fungal and bacterial sampling, respectively. All samples were transferred to the laboratory in a cold box $\left(4^{\circ} \mathrm{c}\right)$ and processed after arrival in the laboratory.

\section{Detection of bacteria and fungi}

The fungal plates were kept at room temperature $\left(25^{\circ} \mathrm{C}\right)$ and read after $72-120 \mathrm{~h}$ and bacterial plates were incubated at $37^{\circ} \mathrm{C}$ for $24-48 \mathrm{~h}$. The total fungal and bacterial concentration was enumerated to colony-forming units per cubic meter $\left(\mathrm{CFU} / \mathrm{m}^{3}\right)$.

Grown fungal colonies on SDA were recognized based on colony's morphology and microscopically identification under magnifications of 10,40,100. Bacterial colonies grown on BA were isolated based on their morphology and by application of different culture media and biochemical tests, bacteria species were recognized.

\section{Results}

The mean concentration of bacterial and fungal bioaerosols in selected 8 wards of the studied hospital is presented in Table 2 . the concentration of bacteria and fungi in hospital wards ranged from 44 to $75 \mathrm{CFU} / \mathrm{m}^{3}$ and 8 to $22 \mathrm{CFU} / \mathrm{m}^{3}$, respectively. Table 3 shows the comparison of bioaerosols presence in morning and afternoon shifts. No significant difference between the two shifts was observed. The presence frequency of bacteria species and fungal genera isolated from each ward is presented in Tables 4 and 5, respectively. Among detected bacteria, Staphylococcus aureus was found more frequently than other bacteria and penicillium was the most frequent in comparison with other fungi genera. The Inpatient Bed Occupancy Rate (IBOR) was calculated during the sampling period and was divided into three categories (less than $71 \%$, between $72 \%$ to $75 \%$ and greater than $76 \%$ ). The highest frequency of bacteria and fungi was observed in the IBOR less than $71 \%$, but statistical analysis did not show a significant relationship between the IBOR and the frequency of microorganisms. The average temperature recorded during sampling was between 24 and $27^{\circ} \mathrm{C}$ and the relative humidity was $30 \%$ to $37 \%$. There was no significant relationship between the concentration and abundance of bacteria and fungi with 
Table 1 Characteristics of the hospital wards

\begin{tabular}{lllll}
\hline Hospital wards & Area $(\mathrm{m} 2)$ & No. of Beds & Ventilation system & Sampling locations \\
\hline Operating Theater & 306 & 4 & HVAC* with HEPA** filter & Near toilet, nurse station, between patient bed \\
Postpartum Care & 384 & 30 & Natural ventilation & Near toilet, nurse station, patient room \\
Surgery & 574 & 31 & Natural ventilation & Near toilet, nurse station, between patient bed \\
NICU & 100 & 12 & HVAC & Near toilet, nurse station, between patient bed \\
Neonatal & 70 & 11 & HVAC & Near toilet, nurse station, room \\
Emergency & 147 & 9 & Natural ventilation & Near toilet, nurse station, between patient bed \\
Maternity & 364 & 11 & Natural ventilation & Near toilet, nurse station, between patient bed \\
LDR & 277 & 7 & HVAC & Near toilet, nurse station, room \\
\hline
\end{tabular}

*Heating, Ventilation, and air conditioning system

**high efficiency particulate air

temperature, but the relationship between fungi and relative humidity was significant.

\section{Discussion}

Indoor air of healthcare settings contains a mixture of bioaerosols such as fungi, bacteria, viruses, and allergens which are originated from different sources include outdoor air, staff and patients (talking, coughing, sneezing), ventilation systems, toilet flushing, and cleaning activities [11, 17]. Among hospital staff, visitors, and patients who are exposed to bioaerosols during their inhabitancy in hospitals, Immunocompromised individuals are at higher risk of probable infections [12, 21]. Therefore, indoor air quality of hospitals is a great concern. In our study, the concentration of airborne bacteria and fungi in hospital wards ranged from 44 to $75 \mathrm{CFU} / \mathrm{m}^{3}$ and 8 to $22 \mathrm{CFU} / \mathrm{m}^{3}$, respectively (Table 2). The average concentrations of detected bacteria and fungi were $57.44 \mathrm{CFU} / \mathrm{m}^{3}$ and $16.13 \mathrm{CFU} / \mathrm{m}^{3}$, respectively, which is in accordance with data found by some authors [9, 22], but lower than that reported by others [17]. Mirhoseini et al. (2015) showed that the mean concentration of airborne bacteria in hospitals of Isfahan city in Iran was $464 \mathrm{CFU} / \mathrm{m}^{3}$ which is much higher than our results [17]. In the study of Montazeri et al. (2020) concentration of fungal and bacterial aerosols in a burn hospital ranged from 32 to $110 \mathrm{CFU} / \mathrm{m}^{3}$ and 53 to $94 \mathrm{CFU} / \mathrm{m}^{3}$, respectively [23]. Generally, due to the presence of more sources and more favorable environmental conditions for bacteria, the concentration of bacteria in hospitals air is higher than fungi concentration [16]. We found lower concentrations of fungi than bacteria in all samples. Consistent with our results Mousavi et al. (2019) and Bolookat et al. reported the higher level of bacteria in hospitals bioaerosols samples [9, 24].

Table 3 shows the comparison of bioaerosols presence in morning and afternoon shifts. No significant difference between the two shifts was observed. It is indicated that in the studied hospital a constant environmental condition is provided. Other studies reported more bioaerosol presence in afternoon shift, they suggested changes in temperature and relative humidity and presence of visitors as the effective factors on higher microbial load in the afternoon shifts $[25,26]$.

There was a significant difference between concentrations of airborne fungi and bacteria in different wards, the mean concentration of bioaerosols was highest in LDR and the

Table 2 Bacterial and fungal concentration of hospital wards air

\begin{tabular}{|c|c|c|c|c|c|c|}
\hline & \multicolumn{2}{|c|}{ Fungal concentration } & \multicolumn{2}{|c|}{ Bacterial concentration } & \multirow{2}{*}{$\begin{array}{l}\text { Total } \\
\text { Mean } \pm \text { SD }\end{array}$} & \multirow[b]{2}{*}{$\mathrm{P}$ value } \\
\hline & Mean \pm SD & $P$ value & Mean \pm SD & $P$ value & & \\
\hline Operating Theater & $14.28 \pm 11.86$ & 0.002 & $48.57 \pm 23.90$ & $<0.001$ & $62.85 \pm 26.42$ & $<0.001$ \\
\hline Postpartum Care & $17.62 \pm 12.83$ & & $56.19 \pm 30.22$ & & $73.81 \pm 34.80$ & \\
\hline Surgery & $18.75 \pm 11.35$ & & $57.13 \pm 23.43$ & & $75.70 \pm 28.61$ & \\
\hline NICU & $8.58 \pm 11.64$ & & $44.29 \pm 28.65$ & & $52.87 \pm 36.21$ & \\
\hline Neonates & $14.75 \pm 11.55$ & & $56.19 \pm 30.69$ & & $70.94 \pm 34.89$ & \\
\hline Emergency & $14.28 \pm 11.86$ & & $75.70 \pm 30.74$ & & $89.99 \pm 33.16$ & \\
\hline Maternity & $18.09 \pm 14.97$ & & $50.94 \pm 26.71$ & & $69.03 \pm 29.08$ & \\
\hline LDR & $22.85 \pm 14.33$ & & $70.47 \pm 27.03$ & & $93.33 \pm 31.33$ & \\
\hline Total & $16.13 \pm 13.03$ & - & $57.44+29.17$ & - & $73.57 \pm 33.88$ & \\
\hline
\end{tabular}


Table 3 Number of isolated bacteria and fungi according to the shift

\begin{tabular}{|c|c|c|c|c|c|c|}
\hline \multirow[t]{2}{*}{ Sampling time } & \multicolumn{2}{|l|}{ Fungi } & \multicolumn{2}{|l|}{ Bacteria } & \multicolumn{2}{|l|}{ Total } \\
\hline & P.value & $\begin{array}{l}\text { Frequency of positive } \\
\text { samples }(\%)\end{array}$ & P.value & $\begin{array}{l}\text { Number of positive } \\
\text { samples (\%) }\end{array}$ & P.value & $\begin{array}{l}\text { Number of positive } \\
\text { samples }(\%)\end{array}$ \\
\hline Morning shift & 0.14 & $86(71.7)$ & 0.386 & 114(95) & 0.185 & $116(96.7)$ \\
\hline Afternoon shift & & $89(74.2)$ & & 118(98.3) & & 119(99.2) \\
\hline Total & - & $175(72.9)$ & - & $232(96.7)$ & - & 235(97.9) \\
\hline
\end{tabular}

lowest in the Neonatal ward (Table 2). Both of these sites used the HAVC system and the concentration differences is probably due to the higher density of people in LDR. However, based on statistical analysis there was no significant differences between natural ventilation and HAVC. Stockwell et al. (2019) reported that the bioaerosols concentration in areas which used mechanical ventilation was significantly less than wards with natural ventilation [12]. The mean concentration of bioaerosols in operating theater was in agreement with some of the other studies $[9,22]$ and lower from Mirhoseini et al. (2015) [17] and Montazeri et al. (2020) [23] in Iran, which might be related to the recent installation of new filters in the ventilation system and occupant density. The results of previous studies are provided in Table 6 .

In the study of Stocks et al. (2010) a relationship between population density and bioaerosols concentration was reported [33]. We used Inpatient Bed Occupancy Rate (IBOR) as the factor of the population of hospitalized patients. Statistical analysis showed no significant relationship between IBOR and bioaerosols concentration. However, it does not mean that the bioaerosols concentration was not affected by the number of patients, because we did not include the number of outpatients in our analysis.
According to our searches, no other study has been performed on a specialized hospital of obstetrics and gynecology, but there are studies that have reported the highest concentration of bioaerosols in the women wards of hospitals [18, 20].

The survival of bioaerosols is influenced by environmental factors include temperature and relative humidity $[12,16]$. In our study, airborne bacterial and fungal concentrations in hospital environments were not significantly related to temperature, but fungal concentration was correlated to relative humidity. Similarly, Obbard and Fang (2003) reported no significant relationship between airborne bacteria and temperature in hospital wards in Singapore, but the relationship between humidity and bacterial level was significant [34]. Contrary to our results, Park et al. (2013) Reported that the presence and concentration of bacteria and fungi are correlated to temperature [35]. Some studies found no significant relationship between bioaerosols and environmental parameters in hospital air $[9,28]$.

Among bacteria, Staphylococcus, Enterococcus and Pseudomonas aeruginosa have been reported to play the most important role in causing nosocomial infections [1].

As is presented in Table 4, staphylococcus aureus (grampositive) and Neisseria (gram-negative) had the most and the

Table 4 Frequency (\%) of diagnosed bacteria in different hospital wards

\begin{tabular}{lllllllllll}
\hline Bacterial Species & $\begin{array}{l}\text { Operating } \\
\text { Theater }\end{array}$ & $\begin{array}{l}\text { Postpartum } \\
\text { Care }\end{array}$ & Surgery & NICU & Neonates & Emergency & Maternity & LDR & Total & P.value \\
\hline $\begin{array}{l}\text { Staphylococcus aureus } \\
\text { Staphylococcus }\end{array}$ & $12(40)$ & $18(60)$ & $12(40)$ & $13(43.3)$ & $18(60)$ & $18(60)$ & $12(40)$ & $13(43.3)$ & $116(48.3)$ & 0.332 \\
$\begin{array}{l}\text { epidermidis } \\
\text { Micrococcus luteus }\end{array}$ & $11(36.7)$ & $16(53.3)$ & $8(26.7)$ & $5(16.7)$ & $8(26.7)$ & $9(30)$ & $9(30)$ & $14(47.6)$ & $80(33.3)$ & 0.067 \\
Micrococcus Roseus & $12(40)$ & $8(26.7)$ & $11(36.7)$ & $7(23.3)$ & $9(30)$ & $10(33.3)$ & $10(33.3)$ & $12(40)$ & $79(32.9)$ & 0.84 \\
Pseudomonas & $6(20)$ & $8(26.7)$ & $10(33.3)$ & $6(20)$ & $9(30)$ & $8(26.7)$ & $6(20)$ & $9(30)$ & $63(26.3)$ & 0.92 \\
$\quad$ Aeruginase & $7(23.3)$ & $8(26.7)$ & $11(36.7)$ & $14(46.7)$ & $11(36.7)$ & $7(23.3)$ & $15(50)$ & $79(32.9)$ & 0.094 \\
Pediocock & $8(26.7)$ & $4(13.3)$ & $8(26.7)$ & $8(26.7)$ & $7(23.3)$ & $7(23.3)$ & $8(26.7)$ & $9(30)$ & $59(24.6)$ & 0.9 \\
Bacillus & $14(46.7)$ & $11(36.7)$ & $9(30)$ & $8(26.7)$ & $10(33.3)$ & $9(30)$ & $8(26.7)$ & $13(43.3)$ & $82(34.2)$ & 0.63 \\
Niseria & $1(3.3)$ & $2(6.7)$ & $1(3.3)$ & $1(3.3)$ & $1(3.3)$ & $4(13.3)$ & $4(13.3)$ & $1(3.3)$ & $15(6.3)$ & 0.4 \\
Enterococcus faecalis & $2(6.7)$ & $4(13.3)$ & $8(26.7)$ & $3(10)$ & $6(20)$ & $7(23.3)$ & $7(23.3)$ & $8(26.7)$ & $47(19.6)$ & 0.19 \\
Streptococcus pyogenes & $7(23.3)$ & $4(13.3)$ & $5(16.7)$ & $2(6.7)$ & $3(10)$ & $4(13.3)$ & $4(13.3)$ & $7(23.3)$ & $37(15.4)$ & 0.58 \\
\begin{tabular}{llllll} 
Other Bacteria \\
\hline
\end{tabular} & $0(0)$ & $1(3.3)$ & $4(13.3)$ & $3(10)$ & $1(3.3)$ & $3(10)$ & $3(10)$ & $1(3.3)$ & $17(7.1)$ & 0.28 \\
\hline
\end{tabular}


Table 5 Frequency (\%) of diagnosed fungi in different hospital wards

\begin{tabular}{|c|c|c|c|c|c|c|c|c|c|c|}
\hline Fungal Genera & Operating Theater & Postpartum Care & Surgery & NICU & Neonates & Emergency & Maternity & LDR & Total & P.value \\
\hline Aspergillus Fumigatus & $2(6.7)$ & $5(16.7)$ & $4(13.3)$ & $2(6.7)$ & $4(13.3)$ & $5(16.7)$ & $4(13.3)$ & $1(3.3)$ & $27(11.3)$ & 0.62 \\
\hline Aspergillus Niger & $3(10)$ & $3(10)$ & $4(13.3)$ & $3(10)$ & $2(6.7)$ & $0(0)$ & $3(10)$ & $3(10)$ & $21(8.8)$ & 0.76 \\
\hline Penicillium & $7(23.3)$ & $6(20)$ & $8(26.7)$ & $2(6.7)$ & $7(23.3)$ & $5(16.7)$ & $7(23.3)$ & $8(26.7)$ & $50(20.8)$ & 0.59 \\
\hline Cladosporium & $6(20)$ & $3(10)$ & $2(6.7)$ & $3(10)$ & $3(10)$ & $2(6.7)$ & $5(16.7)$ & $6(20)$ & $30(12.5)$ & 0.54 \\
\hline Scopolariopsis & $1(3.3)$ & $4(13.3)$ & $2(6.7)$ & $0(0)$ & $3(10)$ & $4(13.3)$ & $1(3.3)$ & $4(13.3)$ & $19(7.9)$ & 0.32 \\
\hline Alternaria & $0(0)$ & $4(13.3)$ & $3(10)$ & $2(6.7)$ & $1(3.3)$ & $3(10)$ & $2(6.7)$ & $4(13.3)$ & $19(7.0)$ & 0.5 \\
\hline Mocur & $1(3.3)$ & $2(6.7)$ & $2(6.7)$ & $2(6.7)$ & $0(0)$ & $1(3.3)$ & $3(10)$ & $1(3.3)$ & $12(5)$ & 0.75 \\
\hline Trichoderma & $1(3.3)$ & $4(13.3)$ & $1(3.3)$ & $2(6.7)$ & $1(3.3)$ & $1(3.3)$ & $1(3.3)$ & $2(6.7)$ & $13(5.4)$ & 0.64 \\
\hline Yeast & $1(3.3)$ & $0(0)$ & $1(3.3)$ & $1(3.3)$ & $3(10)$ & $1(3.3)$ & $2(6.7)$ & $3(10)$ & $12(5)$ & 0.58 \\
\hline Psilomycosis & $2(6.7)$ & $1(3.3)$ & $3(10)$ & $0(0)$ & $1(3.3)$ & $1(3.3)$ & $1(3.3)$ & $3(10)$ & $12(5)$ & 0.58 \\
\hline Unknown & $4(13.3)$ & $5(16.7)$ & $6(20)$ & $1(3.3)$ & $4(13.3)$ & $3(10)$ & $5(16.7)$ & $5(16.7)$ & $33(138)$ & 0.69 \\
\hline
\end{tabular}

least frequency among detected bacteria in hospital wards, respectively. Gram-positive bacteria are more resistant to adverse environmental conditions than gram negatives $[12,21]$. Other studies similar to ours reported a higher frequency of gram-positive bacteria and staphylococcus species $[12,36$, 37]. Staphylococcus aureus mainly causes blood-borne infections [1]. Staphylococcus spp. are very resistant to dry condition [12] and frequently found in the indoor air of hospitals in Iran which is located in a semiarid area [3, 9, 23]. Some studies suggested staphylococcus $s p$. as the indoor air pollution bacterial indicators [38]. Still, Gram-negative bacteria are notable for the release of endotoxins. Although endotoxins have not been studied in this study, some authors showed that exposure to endotoxins can have serious outcomes such as septic shock, chest congestion, and even death [39]. As is seen in Table 5, Pseudomonas aeruginosa (gram-negative) had relatively high frequency in LDR and neonatal ward air samples.

Studies reported Pseudomonas spp. as the main Gramnegative bacteria isolated from hospital wards [11, 21, 23].
Pseudomonas spp. require moisture for survival and growth, so their presence may be attributed to the existence of wash-room in the vicinity of the sampling area or cleaning and moping activities during sampling [40]. Since pseudomonas species are resistant to many disinfectants, it is difficult to eradicate them from hospitals [21, 40, 41]. Pseudomonas aeruginosa has been observed in infections of all parts of the body, especially infections of the kidneys and urinary tract [1].

Enterococcus is involved in causing surgical-site infections [1]. Although in our study Enterococcus was not more common than other isolated bacteria, its highest frequency was observed in the surgery ward $(26 \%)$ which can be alarming.

The predominant fungal genera isolated in indoor air of hospital wards were penicillium and aspergillus species. Inconsistence of our results Montazeri et al. (2020) reported that penicillium was the most frequently isolated fungi from hospital wards [23]. Cladosporium, Penicillium, Aspergillus, Alternaria, Fusarium, and Candida are the most common isolated fungi from hospital air in other studies [11, 36].

Table 6 Bioaerosols concentration (bacteria and fungi) in the previous studies

\begin{tabular}{|c|c|c|c|c|c|}
\hline Author (year) & $\begin{array}{l}\text { Bacterial aerosols } \\
\text { concentration }\end{array}$ & Dominant bacteria & $\begin{array}{l}\text { Fungal aerosols } \\
\text { concentration }\end{array}$ & Dominant Fungi & Country \\
\hline Ekhaise et al. (2011) [27] & 33.5 & Staphylococcus & 31.5 & Aspergillus & Nigeria \\
\hline Nourmoradi et al. (2011) [28] & 254 & Staphylococcus & 214 & Penicillium & Iran \\
\hline Cabo Verde et al. (2015) [16] & 374 & Staphylococcus & 16.5 & Aspergillus & Portugal \\
\hline Maji et al. (2013) [29] & 1641 & Bacillus & 2830 & Aspergillus & India \\
\hline Hoseinzadeh et al. (2013) [18] & 16.05 & Staphylococcus & 18.8 & Aspergillus & Iran \\
\hline Mirzaei et al. (2014) [30] & 56.4 & Staphylococcus & - & - & Iran \\
\hline Mirhoseini et al. (2015) [17] & 464 & - & - & - & Iran \\
\hline Sepahvand et al. (2016) [31] & - & - & 85.7 & Cladosporium & Iran \\
\hline Demirel et al. (2017) [32] & - & - & 47.5 & Penicillium & Turkey \\
\hline Montazeri et al. (2020) [23] & 73.5 & Staphylococcus & 71 & Penicillium & Iran \\
\hline
\end{tabular}


Many studies indicated aspergillus and penicillium as the major fungal causative agent of nosocomial infections $[11,12$, 23]. These species are resistant to dryness and water scarcity and can survive in different parts of hospitals [11].

According to the $\mathrm{WHO}$ guideline $100 \mathrm{CFU} / \mathrm{m}^{3}$ for bacteria and $50 \mathrm{CFU} / \mathrm{m}^{3}$ for fungi are acceptable in the hospital air [42]. In our study, bacterial concentration in wards ranged from 44 to $75 \mathrm{CFU} / \mathrm{m}^{3}$ and fungal concentration ranged from 8 to $22 \mathrm{CFU} / \mathrm{m}^{3}$, which indicates the level of indoor pollution under WHO suggestion.

The most obvious finding of this survey is that the bioaerosols level of the studied hospital is lower than most of the other studies conducted in Iran $[14,17,23]$. Conclusions that can be drawn from bioaerosol detection studies in healthcare settings are highly dependent on study site characteristics and the sampling and detection methodologies used in these studies [11]. In our study, there was only one collection device, so the time of air sampling from all of the selected wards was limited ( $2.5 \mathrm{~min}$ for each sample). Because of the heterogeneous spread of bioaerosols and their different sizes, during the aerosol collection in passive sampling some microorganisms impact on petri dish, while others are still suspended in the air. Therefore, the longer the sampling time, the more detectable microorganisms $[12,43]$. On the other hand, as said before bioaerosols concentration in hospital environments may be affected by climate conditions and seasonal changes, activities, population density, and ventilation efficiency [11].

The hospital building is relatively new and disinfection and cleaning activities are managed appropriately. One of the indoor air bioaerosol sources is outdoor air [36]. In this study, the level of bioaerosols in outdoor air was not determined. However, windows during sampling were closed and natural ventilation was not performed at that time. Azimi et al. (2013) reported that opening windows and doors are the most significant route of high concentration of fungi in the hospital air [14]. Low concentration of bacteria and fungi in this study may be related to Viable But Non Culturable (VBNC) state of fungi and bacteria which in this state bacteria and fungi are not culturable but still alive and can cause infection [17]. Molecular techniques like PCR assay could be used to overcome this problem. Furthermore, we used the impaction technique for sampling. Previous studies have reported lower efficiency of impaction and filtration techniques compared to the liquid impingement sampling [44].

An important issue regarding the treatment and control of nosocomial infections is the determination of antibiotic resistance of microorganisms. It is reported that 50 to $60 \%$ of nosocomial infections are caused by antibiotic-resistant pathogens.

In this study, although the diversity and concentration of microorganisms were determined, the possibility of transmission of these infections through hospital air was not assessed.
Therefore, the possibility or non-possibility of causing risks in these concentrations cannot be assessed. To investigate the possibility of causing infection by microorganisms detected in hospital air, it is recommended that in future studies, quantitative microbial risk assessment be performed using doseresponse models.

\section{Conclusion}

In this study, we found different types and frequencies of bioaersols in different parts of an obstetrics and gynecology hospital, and the highest level was found in LDR. However, bacteria and fungi potentially causing nosocomial infections (such as Staphylococcus aureus, Pseudomonas aeruginosa, and Aspergillus) were frequently found in this study. Although there was no difference in the concentration of bioaerosols in natural and mechanical ventilation, it seems that ventilation efficiency should be improved to reduce the level of bioaerosols. Given that nosocomial infections often affect neonates; it is necessary to assess the risk of nosocomial infections through exposure to hospital air for neonates.

Acknowledgements This study was funded by Kashan University of Medical Sciences under grant number 9759. The authors thank Kashan University of Medical Sciences for its support. The Ethics code of this study was IR.KAUMS.NUHEPM.REC.1397.025.

\section{Declarations}

Conflict of interest The authors declare there is no conflict of interest.

\section{References}

1. Khan HA, Baig FK, Mehboob R. Nosocomial infections: epidemiology, prevention, control and surveillance. Asian Pac J trop biomed [internet]. Elsevier B.V.; 2017;7:478-82. Available from. 2017. https://doi.org/10.1016/j.apjtb.2017.01.019.

2. WHO. The Burden of Health Care-Associated Infection Worldwide. A Summary; 2010. Geneva; 2016.

3. Mirhoseini SH, Nikaeen M, Shamsizadeh Z. Occurrence of airborne methicillin-resistant Staphylococcus aureus in different hospital wards. EnvironmentAsia. 2019;12:121-8.

4. Karimi H, Nikaeen M, Gholipour S, Hatamzadeh M, Hassanzadeh A, Hajizadeh Y. PM2.5-associated bacteria in ambient air: Is PM2.5 exposure associated with the acquisition of community-acquired staphylococcal infections? J Environ Heal Sci Eng. 2020.

5. Torkashvand J, Jonidi Jafari A, Godini K, Kazemi Z, Kazemi Z, Farzadkia M. Municipal solid waste management during COVID19 pandemic: a comparison between the current activities and guidelines. J Environ Heal Sci Eng [Internet]. 2021; Available from. https://doi.org/10.1007/s40201-020-00591-9.

6. Torkashvand J, Jafari AJ, Hopke PK, Shahsavani A, Hadei M, Kermani M. Airborne particulate matter in Tehran's ambient air. J Environ Heal Sci Eng [Internet]. 2021; Available from. https://doi. org/10.1007/s40201-020-00573-X. 
7. Torkashvand J, Pasalari H, Jonidi-Jafari A, Kermani M, Nasri O, Farzadkia M. Medical waste management in Iran and comparison with neighbouring countries. Int J Environ Anal Chem. Taylor and Francis Ltd. 2020.

8. Gholipour S, Nikaeen M, Manesh RM, Aboutalebian S, Shamsizadeh Z, Nasri E, et al. Severe Acute Respiratory Syndrome Coronavirus 2 (SARS-CoV-2) Contamination of Hightouch Surfaces in Field Settings*. Biomed Environ Sci [Internet]. 2020;(33):925-9 Available from: https://www.sciencedirect.com/ science/article/pii/S0895398821000040.

9. Mousavi MS, Hadei M, Majlesi M, Hopke PK, Yarahmadi M, Emam B, et al. Investigating the effect of several factors on concentrations of bioaerosols in a well-ventilated hospital environment. Environ Monit Assess. Environ Monit Assess; 2019;191.

10. Mirhoseini SH, Nikaeen M, Shamsizadeh Z, Khanahmad H. Hospital air: a potential route for transmission of infections caused by $\beta$-lactam-resistant bacteria. Am J infect control [internet]. Elsevier Inc. 2016;44:898-904. Available from. https://doi.org/ 10.1016/j.ajic.2016.01.041.

11. Zemouri C, De Soet H, Crielaard W, Laheij A. A scoping review on bio-aerosols in healthcare \& the dental environment. PLoS One. 2017;12:1-25.

12. Stockwell RE, Ballard EL, O'Rourke P, Knibbs LD, Morawska L, Bell SC. Indoor hospital air and the impact of ventilation on bioaerosols: a systematic review. J Hosp infect [internet]. The Healthcare Infection Society. 2019;103:175-84. Available from. https://doi.org/10.1016/j.jhin.2019.06.016.

13. Li CS, Hou PA. Bioaerosol characteristics in hospital clean rooms. Sci Total Environ. 2003;305:169-76.

14. Azimi F, Naddafi K, Nabizadeh R, Hassanvand MS, Alimohammadi M, Afhami S, et al. Fungal air quality in hospital rooms: a case study in Tehran. Iran J Environ Heal Sci Eng. 2013;11:2-5.

15. Hosseini N, Hajizadeh Y, Nikaeen M, Hatamzadeh M. Spatiotemporal variation of ambient bioaerosols in a large and industrialized metropolis of Iran and their association with PM2.5 and meteorological factors. Aerobiologia (Bologna) [internet]. Springer Netherlands. 2020;6. Available from. https://doi.org/10. 1007/s10453-020-09672-6.

16. Cabo Verde S, Almeida SM, Matos J, Guerreiro D, Meneses M, Faria T, et al. Microbiological assessment of indoor air quality at different hospital sites. Res Microbiol. 2015;166:557-63.

17. Mirhoseini SH, Nikaeen M, Khanahmad H, Hatamzadeh M, Hassanzadeh A. Monitoring of airborne bacteria and aerosols in different wards of hospitals - particle counting usefulness in investigation of airborne bacteria. Ann Agric Environ Med. 2015;22: 670-973.

18. Hoseinzadeh E, Samarghandie MR, Ghiasian SA, Alikhani MY, Roshanaie G. Evaluation of bioaerosols in five educational hospitals wards air in Hamedan, during 2011-2012. Jundishapur J Microbiol. 2013;6:1-8.

19. Knibbs LD, Morawska L, Bell SC, Grzybowski P. Room ventilation and the risk of airborne infection transmission in 3 health care settings within a large teaching hospital. Am J Infect Control. Elsevier. 2011;39:866-72.

20. Noroozi R, Noorisepehr M. Qualitative and Guantitative Evaluation of Air Pollution in the Panjom Azar and Sayyad Shirazi Hospitals of Gorgan. J Environ Heal Enginering. Alborz University of Medical Sciences. 2016;3:155-68.

21. Gilbert Y, Veillette M, Duchaine C. Airborne bacteria and antibiotic resistance genes in hospital rooms. Aerobiologia (Bologna). 2010;26:185-94.

22. Sudharsanam S, Srikanth P, Sheela M, Steinberg R. Study of the indoor air quality in hospitals in South Chennai, India - microbial profile. Indoor built environ. SAGE publications SAGE UK: London. England. 2008;17:435-41.
23. Montazeri A, Zandi H, Teymouri F, Soltanianzadeh Z, Jambarsang S, Mokhtari M. Microbiological analysis of bacterial and fungal bioaerosols from burn hospital of Yazd (Iran) in 2019. J Environ Heal Sci Eng. 2020.

24. Bolookat F, Hassanvand MS, Faridi S, Hadei M, Rahmatinia M, Alimohammadi M. Assessment of bioaerosol particle characteristics at different hospital wards and operating theaters: a case study in Tehran. MethodsX [Internet]. 2018;5:1588-96 Available from: http:// www.sciencedirect.com/science/article/pii/S2215016118302024.

25. Bhatia L, Vishwakarma R. Hospital indoor airborne microflora in private and government-owned hospitals in Sagar City. India World J Med Sci. 2010;5:65-70.

26. Qudiesat K, Abu-Elteen K, Elkarmi A, Hamad M, Abussaud M. Assessment of airborne pathogens in healthcare settings. African J Microbiol Res Academic Journals. 2009;3:66-76.

27. Ekhaise FO, Ogboghodo BI. Microbiological indoor and outdoor air quality of two major hospitals in Benin City. Nigeria Sierra Leone J Biomed Res. 2011;3:169-74.

28. Nourmoradi H, Nikaeen M, Amin MM, Hatamzadeh M. An investigation on bio-aerosol concentrations in the different wards of hospitals of Isfahan University of Medical Sciences. J Isfahan Med Sch. 2011;29.

29. Maji S, Ghosh S, Ahmed S. Association of air quality with respiratory and cardiovascular morbidity rate in Delhi. India Int J Environ Health Res Taylor \& Francis. 2018;28:471-90.

30. Mirzaei R, Shahriary E, Qureshi MI, Rakhshkhorshid A, Khammary A, Mohammadi M. Quantitative and qualitative evaluation of bio-aerosols in surgery rooms and emergency department of an educational hospital. Jundishapur J Microbiol. 2014;7:6-10.

31. Sepahvand A, SHAMS GM, Allameh A, RAZZAGHI AM. Diversity and distribution patterns of airborne microfungi in indoor and outdoor hospital environments in Khorramabad, Southwest Iran. JUNDISHAPUR JOURNAL OF MICROBIOLOGY (JJM). 2013.

32. Demirel R, Sen B, Kadaifciler D, Yoltas A, Okten S, Ozkale E, et al. Indoor airborne fungal pollution in newborn units in Turkey. Environ Monit Assess Springer. 2017;189:1-11.

33. Stocks GW, Self SD, Thompson B, Adame XA, O'Connor DP. Predicting bacterial populations based on airborne particulates: a study performed in nonlaminar flow operating rooms during joint arthroplasty surgery. Am J Infect Control Elsevier. 2010;38:199204.

34. Obbard JP, Fang LS. Airborne concentrations of bacteria in a hospital environment in Singapore. Water Air Soil Pollut Springer. 2003;144:333-41.

35. Park DU, Yeom JK, Lee WJ, Lee KM. Assessment of the levels of airborne bacteria, gram-negative bacteria, and fungi in hospital lobbies. Int J Environ Res Public Health. 2013;10:541-55.

36. Chaivisit P, Fontana A, Galindo S, Strub C, Choosong T, Kantachote D, et al. Airborne bacteria and fungi distribution characteristics in natural ventilation system of a university hospital in Thailand. EnvironmentAsia. 2018;11:53-66.

37. Awosika SA, Olajubu FA, Amusa NA. Microbiological assessment of indoor air of a teaching hospital in Nigeria. Asian Pac J trop biomed [internet]. Asian Pacific tropical Biomedical magazine. 2012;2:465-8. Available from. https://doi.org/10.1016/S22211691(12)60077-X.

38. Chegini FM, Baghani AN, Hassanvand MS, Sorooshian A, Golbaz $\mathrm{S}$, Bakhtiari R, et al. Indoor and outdoor airborne bacterial and fungal air quality in kindergartens: seasonal distribution, genera, levels, and factors influencing their concentration. Build environ [internet]. Elsevier ltd. 2020;175:106690. Available from. https:// doi.org/10.1016/j.buildenv.2020.106690.

39. Humbal C, Gautam S, Trivedi U. A review on recent progress in observations, and health effects of bioaerosols. Environ Int 
[internet]. Elsevier. 2018;118:189-93. Available from. https://doi. org/10.1016/j.envint.2018.05.053.

40. Rughooputh S. The role of Pseudomonas Aeruginosa in Nosocomical infections. Biomed Sci Institute Of Biomedical Science. 2001;45:463-8.

41. Naruka K, Guar J, Chraya R. Bioaerosols in Healthcare Settings : a Brief Review Bioaerosols in Healthcare Settings : a Brief Review 2017;4:59-64.

42. WHO. Guidelines for indoor air quality: selected pollutants. Regional Office for Europe: World Health Organization; 2010.
43. Morawska L. Droplet fate in indoor environments, or can we prevent the spread of infection? Proc Indoor Air 2005 10th Int Conf Indoor Air Qual Clim. Springer; 2005. p. 9-23.

44. Deloge-Abarkan M, Ha T-L, Robine E, Zmirou-Navier D, Mathieu L. Detection of airborne Legionella while showering using liquid impingement and fluorescent in situ hybridization (FISH). J Environ Monit Royal Society of Chemistry. 2007;9:91-7.

Publisher's note Springer Nature remains neutral with regard to jurisdictional claims in published maps and institutional affiliations. 